\title{
Correlation between faecal indicator bacteria in diarrheagenic stools and hospital wastewaters: implication on public health
}

\author{
Olalemi, A., Oladejo, B., and *Bayode, M. \\ Department of Microbiology, Federal University of Technology, P.M.B. 704, Akure, Nigeria \\ *Correspondence to: bayodemcbay@gmail.com
}

\begin{abstract}
:
Background: Hospital wastewaters contain blends of inorganic, natural constituents and contaminants that carry significant health risk when released directly into the environment. The aim of this study is to investigate the correlation between faecal indicator bacteria in diarrheagenic stools and wastewaters generated in University of Medical Sciences Teaching Hospital complex, Akure, Nigeria.

Methodology: Quantification of faecal indicator bacteria was carried out on diarrheagenic faecal samples collected from 55 hospitalized patients and 68 wastewater samples from the medical laboratory science and laundry units of the hospital over of period of 12 weeks. Standard membrane filtration technique was performed using membrane intestinal enterococcus (m-ENT), membrane faecal coliform ( $m-F C)$, membrane lauryl sulphate (MLSA), eosin methylene blue (EMB) and Salmonella-Shigella (SS) agar plates, which were incubated at $37^{\circ} \mathrm{C}$ for 24 hours (MLSA, EMB and SSA), $44^{\circ} \mathrm{C}$ for 24 hours $(\mathrm{m}-\mathrm{FC})$; and $37^{\circ} \mathrm{C}$ for 48 hours ( $\mathrm{m}$-ENT). Bacterial colonies on agar plates were counted and expressed as colony forming units (CFU) per $100 \mathrm{ml}$ of diarrheagenic stool and wastewater. Pearson's correlation analysis was used to determine the relationship between the level of faecal indicator bacteria in diarrheagenic stools and wastewaters at $p<0.05$ level of significance (and 95\% confidence interval).

Results: The faecal coliform counts (log $10 \mathrm{CFU} / 100 \mathrm{ml}$ ) ranged from 1.18 to 1.54 in diarrheagenic stools, 1.32 to1.64 in laboratory wastewater and 1.08 to 2.19 in laundry wastewater. Escherichia coli count (log $10 \mathrm{CFU} / 100 \mathrm{ml})$ ranged from 1.08 to 1.40 in diarrheagenic stools, 1.20 to 1.86 in laboratory wastewater and 0.30 to 1.81 in laundry wastewater. Intestinal enterococci count $(\log 10 \mathrm{CFU} / 100 \mathrm{ml})$ ranged from 0 to 0.30 in diarrheagenic stools, 0.78 to 0.90 in laboratory wastewaters and 0.48 to 1.11 in laundry wastewaters. Pearson's correlation co-efficient showed that all the faecal indicator bacteria count in diarrheagenic faecal samples exhibited positive correlation with those in laboratory wastewaters, but not with those from laundry wastewaters.

Conclusion: The findings suggest that diarrheagenic stools should be properly disinfected after the performance of laboratory tests to prevent transmission of potential pathogens, and wastewater generated from hospitals should be treated prior to discharge into the environment, to prevent possible infections in the community.
\end{abstract}

Keywords: Correlation, faecal indicator bacteria, public health, transmission, wastewater

Copyright 2021 AJCEM Open Access. This article is licensed and distributed under the terms of the Creative Commons Attrition 4.0 International License <a rel="license" href="http://creativecommons.org/licenses/by/4.0/", which permits unrestricted use, distribution and reproduction in any medium, provided credit is given to the original author(s) and the source. Editor-in-Chief: Prof. S. S. Taiwo

\section{Corrélation entre les bactéries indicatrices fécales dans les selles diarrhéiques et les eaux usées des hôpitaux: implication sur la santé publique}

\author{
Olalemi, A., Oladejo, B., et *Bayode, M. \\ Département de microbiologie, Université fédérale de technologie, P.M.B. 704, Akure, Nigéria \\ *Correspondance à: bayodemcbay@gmail.com
}




\section{Abstrait:}

Contexte: Les eaux usées des hôpitaux contiennent des mélanges de constituants inorganiques et naturels et de contaminants qui présentent des risques importants pour la santé lorsqu'ils sont rejetés directement dans l'environnement. Le but de cette étude est d'étudier la corrélation entre les bactéries indicatrices fécales dans les selles diarrhéiques et les eaux usées générées dans le complexe de l'hôpital universitaire des sciences médicales, Akure, Nigeria.

Méthodologie: La quantification des bactéries fécales indicatrices a été réalisée sur des échantillons fécaux diarrhéiques prélevés sur 55 patients hospitalisés et 68 échantillons d'eaux usées du laboratoire médical scientifique et des unités de blanchisserie de l'hôpital sur une période de 12 semaines. La technique de filtration membranaire standard a été réalisée à l'aide de plaques de gélose à entérocoque intestinal membranaire ( $m$-ENT), coliforme fécal membranaire ( $m-F C)$, laurylsulfate membranaire (MLSA), éosine bleu de méthylène (EMB) et gélose SalmonellaShigella (SS), qui étaient incubé à $37^{\circ} \mathrm{C}$ pendant 24 heures (MLSA, EMB et SSA), $44^{\circ} \mathrm{C}$ pendant 24 heures ( $\mathrm{m}-\mathrm{FC}$ ); et $37^{\circ} \mathrm{C}$ pendant 48 heures $(\mathrm{m}-\mathrm{ENT})$. Les colonies bactériennes sur des plaques de gélose ont été comptées et exprimées en unités formant colonies (CFU) pour $100 \mathrm{ml}$ de selles diarrhéiques et d'eaux usées. L'analyse de corrélation de Pearson a été utilisée pour déterminer la relation entre le niveau de bactéries fécales indicatrices dans les selles diarrhéiques et les eaux usées à $p<0,05$ niveau de signification (et intervalle de confiance à 95\%). Résultats: Le nombre de coliformes fécaux $(\log 10 \mathrm{CFU} / 100 \mathrm{ml})$ variait de 1,18 à 1,54 dans les selles diarrhéiques, de 1,32 à 1,64 dans les eaux usées de laboratoire et de 1,08 à 2,19 dans les eaux usées de lessive. Le nombre d'Escherichia coli ( $\log 10 \mathrm{UFC} / 100 \mathrm{ml}$ ) variait de 1,08 à 1,40 dans les selles diarrhéiques, de 1,20 à 1,86 dans les eaux usées de laboratoire et de 0,30 à 1,81 dans les eaux usées de lessive. Le nombre d'entérocoques intestinaux $(\log 10 \mathrm{UFC} / 100 \mathrm{ml})$ variait de 0 à 0,30 dans les selles diarrhéiques, de 0,78 à 0,90 dans les eaux usées de laboratoire et de 0,48 à 1,11 dans les eaux usées de lessive. Le coefficient de corrélation de Pearson a montré que tous les comptages de bactéries fécales indicatrices dans les échantillons fécaux diarrhéiques présentaient une corrélation positive avec ceux des eaux usées de laboratoire, mais pas avec ceux des eaux usées de lessive.

Conclusion: Les résultats suggèrent que les selles diarrhéiques doivent être correctement désinfectées après la réalisation des tests de laboratoire pour éviter la transmission d'agents pathogènes potentiels, et que les eaux usées générées par les hôpitaux doivent être traitées avant d'être rejetées dans l'environnement, afin de prévenir d'éventuelles infections dans la communauté.

Mots clés: corrélation, bactéries indicatrices fécales, santé publique, transmission, eaux usées

\section{Introduction:}

Hospice discharges remain a specific instance of anthropogenic contaminants. The aqueous hospital wastes are intricate blends of inorganic and natural constituents which are frequently dislodged into the immediate vicinity (1). This assortment is the consequence of analytical research laboratory outcomes. Waste and drugs including active by-products from pharmaceutical exhibits and their matters, synthetics, sterilizing agents, specific cleaners, irradiated indicators, bacteria and their antimicrobial resistant genes are sometimes present in hospital wastewaters (1). These wastewaters spawn from all therapeutic and non-medical activities from the laboratory to laundry activities (2). They are also a catalogue of microorganisms, disinfectants and drug wastes (3).

Faecal indicator bacterial (FIB) species are commensal-like bacteria found in the alimentary canal of warm-blooded animals, including humans $(4,5)$. FIB species are used to examine faecal contamination intensities and therefore the prospect of pathogens of faecal source in soils and water in equally humid and temperate systems (6). FIB species comprise Escherichia coli, Salmonella spp, Enterococcus spp, and the coliforms. Globally, these groups of microorganisms are acceptable as useful indicators of faecal contamination since they exhibit close relationship with health hazards associated with gastrointestinal symptoms (7). Escherichia coli is reflected to be a more explicit pointer of faecal pollution than faecal coliforms since the broader test for faecal coliforms also detects thermotolerant nonfaecal coliform bacteria (8). Enterococci are currently the lone FIB endorsed by the United States Environmental Protection Agency (9) for salty and marine waters, since they compare superiorly with human wellbeing effects than further FIB such as faecal coliforms or $E$. coli $(10,11)$.

Most bacteria consortia of gastrointestinal infections such as Shigella, Campylobacter, Salmonella and Escherichia coli are pathogenic in nature (12), one of which Shigella plays a central role in the occurrence of inflammatory diarrhea (13). Hospital-acquired gastroenteritis is an ordinary snag in hospitalized patients but its basis and implications are often taken for granted. Diarrhea illnesses among these patients may be associated with considerable morbidity or mortality $(14,15,16)$. Hospital - acquired gastroenteritis constitutes a heightened incidence of diarrhea 
in hospitalized patients that was not experienced prior to admission but commences after more than three days of hospital duration stay $(17,18,19)$. Medically, this description is constructive since there is a possibility of community-acquired viral, bacterial or parasitic gastroenteritis budding later than the 3-day duration of hospital stay (17), although, in hospitalized patients, administration of antimicrobials and other medical approaches may cause diarrhea by unsettling the host-intestinal microbiome association $(18,20,21,22)$.

Hospital wastewater may contain undesirable latent pathogens including antibioticresistant bacteria, and viruses $(23,24)$. These innocuous agents, which may linger in wastewater treatment plants can aggravate contamination of the normal milieu by instigating natural bio-disproportion (25). The effluents from hospice wastewater treatment plants (WWTPs) are often discharged into surface waters (e.g., rivers, streams, lakes). Potential hazards as a result of these effluents in aquatic environments depend largely on the composition of the effluents, degree of treatment of the effluents, absorption of composites in wastewater, and water current rate of the receiving-river or stream (26). This contamination may lead to multiple environmentally-related risks such as sewage pollution of rivers, streams and other surrounding waters $(27,28)$.

The World Health Organization (29) stated that about $85 \%$ of hospice wastes in the United States are harmless, 10\% infective and $5 \%$ non-infective (but harmful), and infectivity outcomes may differ due to factors related to environmental setup (28). In the absence of hospital WWTPs, pathogenic bacteria may be discharged directly into aquatic reservoirs. The release of untreated hospice effluents directly into the environment may increase the volume of biological materials and critical nutrients that can impact variations in the quality of the receiving environment (30). In addition, hospital wastewater effluents are not odorless and microbial decomposition processes in the effluents may lead to air pollution and cause respiratory problems in humans residing in the surrounding environment and ecosystem (31). The rationale for this study was to investigate the correlation between faecal indicator bacteria in diarrheagenic stools and wastewaters generated from the laboratory and laundry of the University of Medical Sciences Teaching Hospital Complex, Akure, Nigeria. This is to gain an improved comprehension of the risk of onward transmission of potential pathogens in hospital settings as well as the impact of untreated or partially treated hospital wastewaters discharged into the surrounding milieu.

\section{Materials and method:}

\section{Study area}

The study setting, the University of Medical Sciences Teaching Hospital, Akure (UNIMEDTH) (coordinates 7.24210 N, $5.1957^{\circ}$ $E)$, is a state-owned teaching hospital located in Akure South Local Government Area of Ondo State, Nigeria (Fig 1).

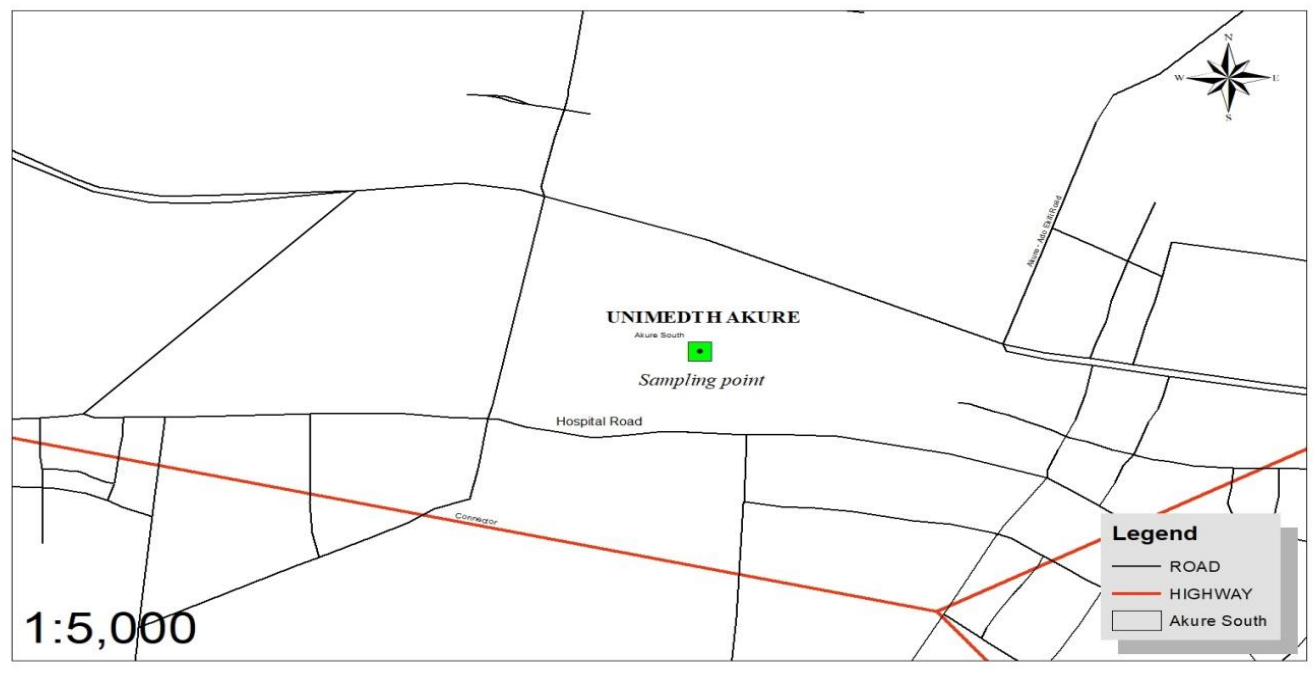

Fig. 1: Locality map showing University of Medical Sciences Teaching Hospital, Akure 


\section{Sample collection}

Five millimeters of diarrheagenic faecal samples were collected from 55 hospitalized patients into sterile red-capped bottles and 500 $\mathrm{ml}$ of 68 wastewater samples were collected into sterile one litre plastic bottles from medical laboratory science and laundry units of the hospital over a period of 12 weeks. Samples were stored in ice packs at a temperature of $4^{\circ} \mathrm{C}$ and analyzed within 1 hour of collection.

\section{Enumeration of bacteria in diarrheagenic faecal stool and wastewater samples}

Membrane filtration was performed according to the method of Maheux et al., (32), with slight modification. The selective media used; membrane intestinal enterococci (mENT), membrane faecal coliform (m-FC), membrane lauryl sulphate agar (MLSA), eosine methylene blue (EMB) and Salmonella-Shigella agar (SSA), were prepared according to the manufacturers' specification. The membrane filters $(0.45 \mu \mathrm{m}$, Delson Pascal Nig. Ltd) were positioned on the freshly prepared selective media. Agar plates were incubated at $37^{\circ} \mathrm{C}$ for
24 hours (MLSA, EMB, SSA), 44응 24 hours (m-FC) and $37^{\circ} \mathrm{C}$ for 48 hours (m-ENT). Colonies (purple for faecal coliforms, metallic green for $E$. coli, dark brown for intestinal enterococci, black for Salmonella and colourless for Shigella) were counted using J 2 colony meter (Pec Medical, USA), calculated and expressed as colony-forming units (CFU) per $100 \mathrm{ml}$ of diarrheagenic stools and wastewaters (Fig 2).

\section{Statistical analysis}

Data obtained were converted to log10 and subjected to general descriptive statistics. Analysis of variance (ANOVA) and test of significance using Duncan's new multiple range test were undertaken using Statistical Package for the Social Sciences (SPSS) version 20.0. All data were analysed by Pearson's correlation at $p<0.05$ level of significance representing $95 \%$ confidence interval, to determine the relationship between the level of faecal indicator bacteria in diarrheagenic stools of hospitalized patients and wastewaters generated from the laboratory and laundry units.

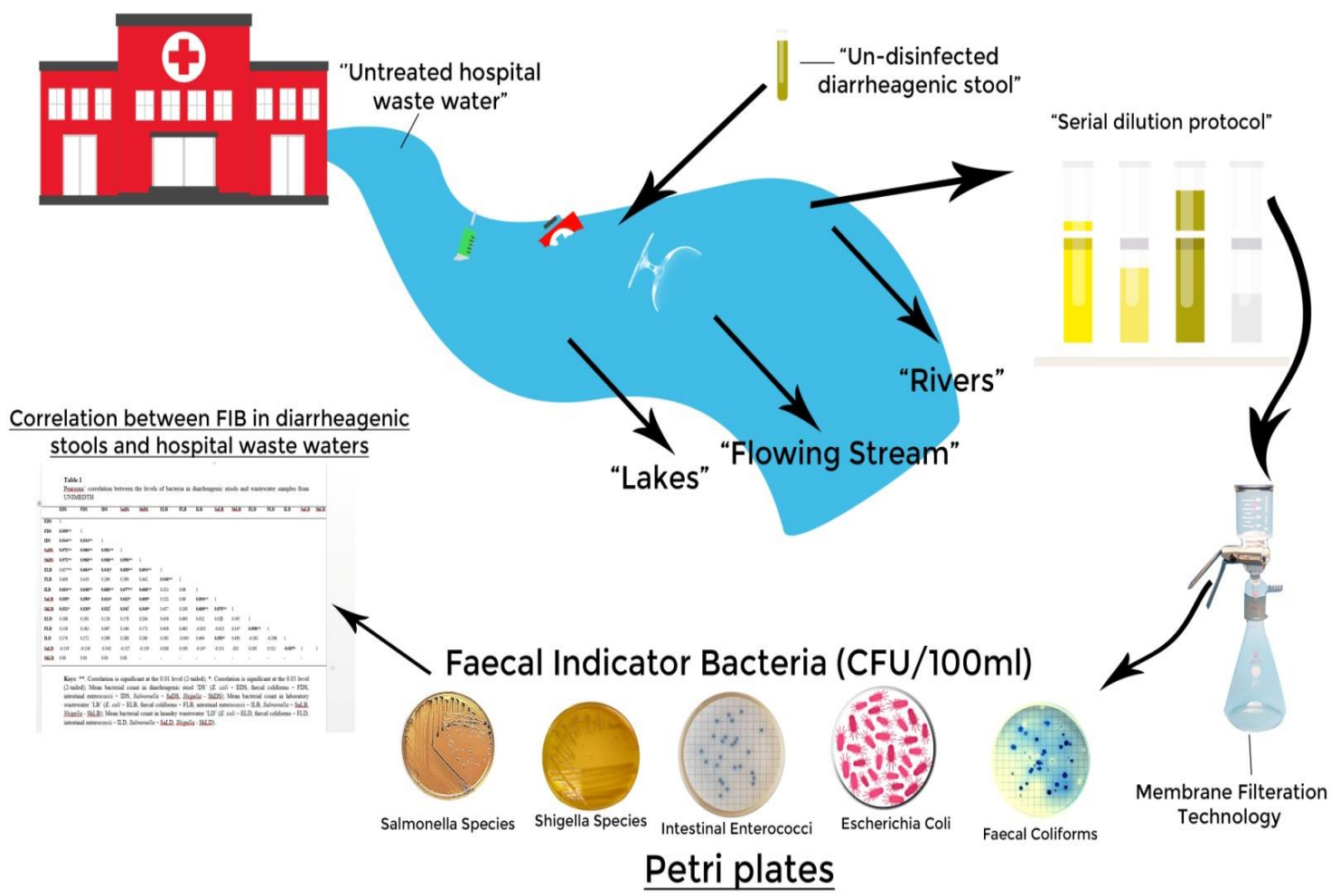

Fig. 2: A graphical illustration of the explanatory synopsis of the correlation of faecal marker bacteria in diarrheagenic stools and hospice effluents 


\section{Results:}

\section{Detection of bacteria in diarrheagenic faecal} samples

Faecal coliforms had the highest mean count of $1.34 \log 10 \mathrm{CFU} / 100 \mathrm{ml}$ while intestinal enterococci had the lowest mean count of 0.30 log10CFU/100ml in diarrheagenic stool. Escherichia coli, Salmonella spp, and Shigella spp had mean counts of 1.28 log $10 C F U / 100 \mathrm{ml}$, $1.04 \log 10 \mathrm{CFU} / 100 \mathrm{ml}$ and $1.15 \mathrm{log} 10 \mathrm{CFU} / 100$ $\mathrm{ml}$ respectively (Fig 3 ).

\section{Detection of bacteria in wastewater samples}

Faecal coliforms had the highest mean count of $1.73 \log 10 \mathrm{CFU} / 100 \mathrm{ml}$ and $1.72 \log 10$
CFU/100ml in laboratory and laundry wastewater samples respectively while intestinal enterococci had the lowest mean count of 0.85 log10CFU/100ml and $0.95 \mathrm{log} 10 \mathrm{CFU} / 100 \mathrm{ml}$ in laboratory and laundry wastewater samples respectively. The respective mean counts in laboratory and laundry wastewater samples for E. coli were $1.61 \mathrm{log} 10 \mathrm{CFU} / 100 \mathrm{ml}$ and 1.69 log10CFU/100ml, Salmonella spp, $1.08 \log 10$ CFU/100ml and $1.62 \log 10 \mathrm{CFU} / 100 \mathrm{ml}$, and Shigella spp $1.40 \mathrm{log} 10 \mathrm{CFU} / 100 \mathrm{ml}$ and 1.53 log10CFU/100ml. The bacterial counts in the laundry wastewater samples were multiple than those in the laboratory wastewater samples (Fig 4).

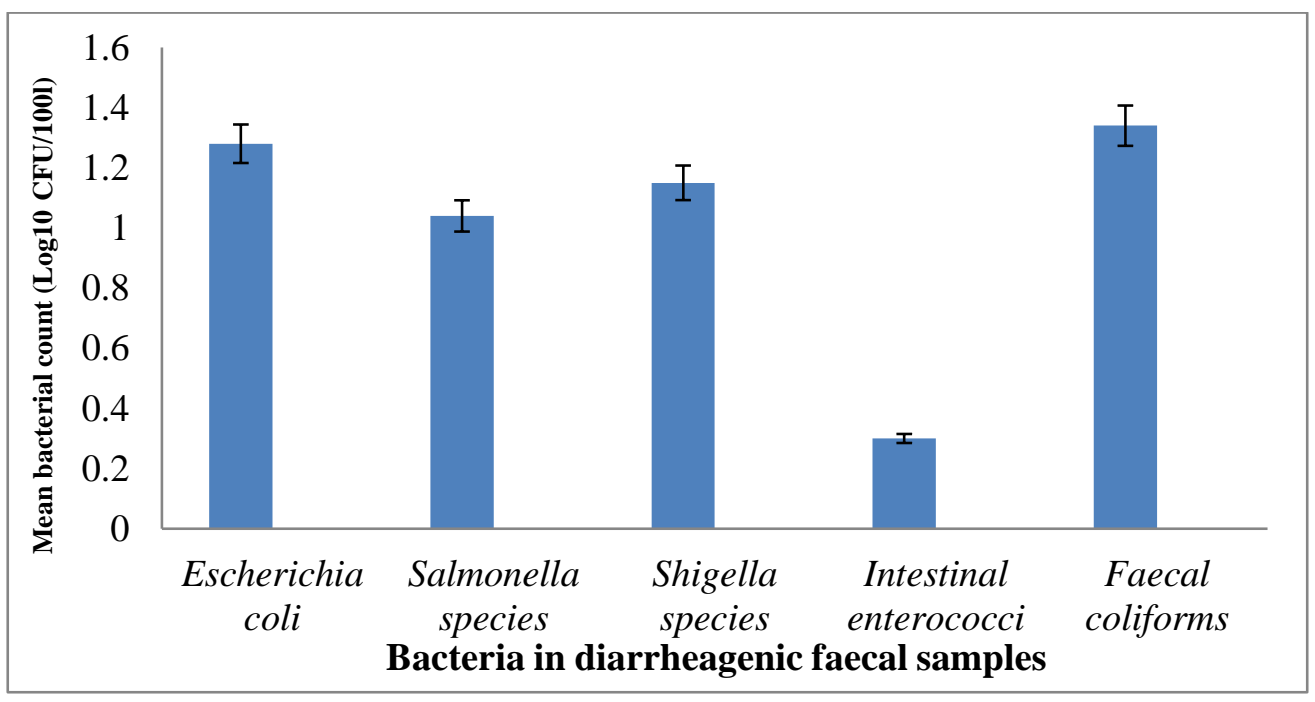

Fig. 3. Mean count of targeted bacterial indicators in diarrheagenic faecal samples

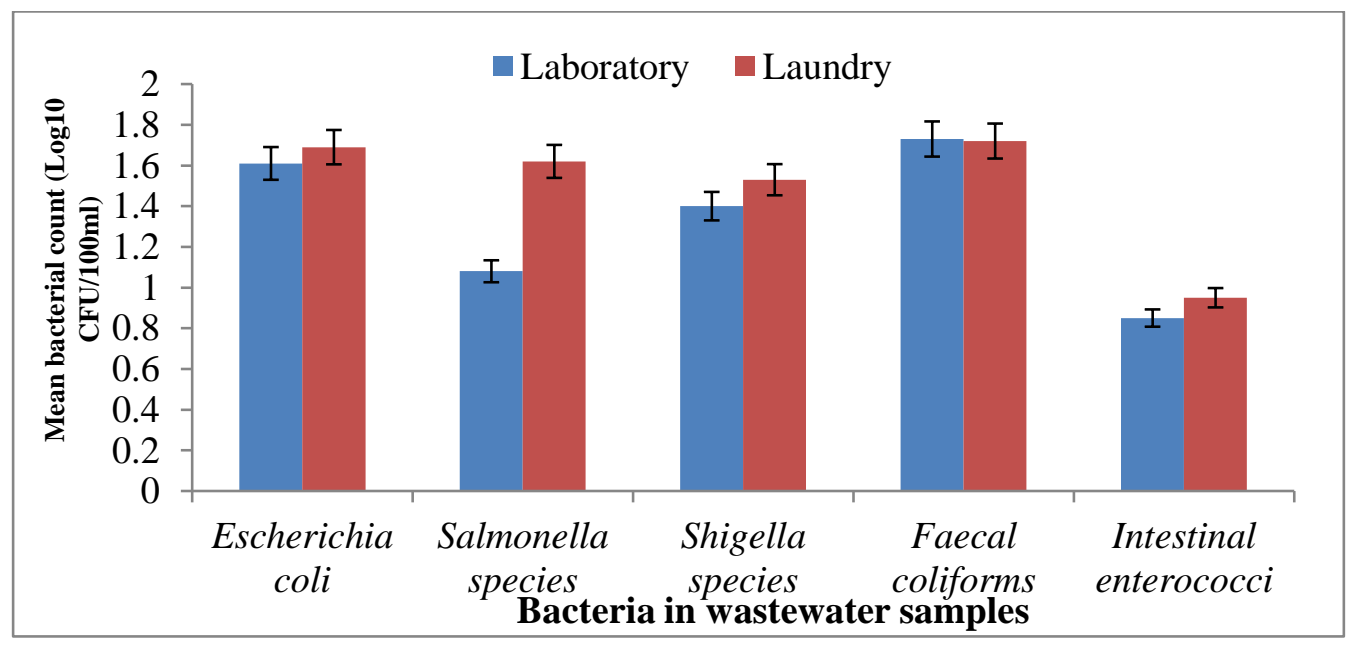

Fig. 4. Mean count of bacterial indicators in laboratory and laundry wastewater samples 
Table 1: Pearson's correlation between bacteria counts in diarrheagenic stools and wastewater samples

\begin{tabular}{|c|c|c|c|c|c|c|c|c|c|c|c|c|c|c|c|}
\hline & EDS & FDS & IDS & $\mathrm{SaDS}$ & ShDS & $E L B$ & FLB & ILB & SaLB & ShLB & ELD & FLD & ILD & SaLD & ShLD \\
\hline EDS & 1 & & & & & & & & & & & & & & \\
\hline FDS & $0.999 * *$ & 1 & & & & & & & & & & & & & \\
\hline IDS & $0.944^{* *}$ & $0.934 * *$ & 1 & & & & & & & & & & & & \\
\hline $\mathrm{SaDS}$ & $0.972^{* *}$ & $0.966 * *$ & $0.981 * *$ & 1 & & & & & & & & & & & \\
\hline ShDS & $0.972^{* *}$ & $0.968 * *$ & $0.968^{* *}$ & $0.998 * *$ & 1 & & & & & & & & & & \\
\hline ELB & $0.657^{* *}$ & $0.664^{* *}$ & $0.542^{*}$ & $0.650^{* *}$ & $0.694^{* *}$ & 1 & & & & & & & & & \\
\hline FLB & 0.408 & 0.419 & 0.269 & 0.390 & 0.442 & $0.940 * *$ & 1 & & & & & & & & \\
\hline ILB & $0.654^{* *}$ & $0.648 * *$ & $0.680^{* *}$ & $0.677^{* *}$ & $0.668^{* *}$ & 0.331 & 0.68 & 1 & & & & & & & \\
\hline SaLB & $0.595 *$ & $0.590 *$ & $0.614^{*}$ & $0.615 *$ & $0.609 *$ & 0.322 & 0.89 & $0.894 * *$ & 1 & & & & & & \\
\hline ShLB & $0.531^{*}$ & $0.530 *$ & 0.512 & 0.541 & $0.549 *$ & 0.457 & 0.300 & $0.669 * *$ & $0.875^{* *}$ & 1 & & & & & \\
\hline ELD & 0.188 & 0.193 & 0.118 & 0.178 & 0.204 & 0.458 & 0.493 & 0.012 & 0.016 & 0.367 & 1 & & & & \\
\hline FLD & 0.156 & 0.162 & 0.087 & 0.146 & 0.172 & 0.438 & 0.485 & -0.033 & -0.015 & 0.347 & $0.998 * *$ & 1 & & & \\
\hline ILD & 0.276 & 0.272 & 0.299 & 0.288 & 0.280 & 0.383 & -0.045 & 0.464 & $0.593^{*}$ & 0.493 & -0.261 & -0.298 & 1 & & \\
\hline SaLD & -0.119 & -0.116 & -0.142 & -0.127 & -0.119 & 0.026 & 0.100 & -0.247 & -0.311 & -202 & 0.293 & 0.312 & $-0.567^{*}$ & 1 & 1 \\
\hline ShLD & 0.00 & 0.00 & 0.00 & 0.00 & - & - & - & - & - & - & - & - & - & - & \\
\hline
\end{tabular}

**. Correlation is significant at the 0.01 level (2-tailed); ${ }^{*}$. Correlation is significant at the 0.05 level (2-tailed); Mean bacterial count in diarrheagenic stool 'DS' (E. coli - EDS, faecal coliforms - FDS, intestinal enterococci - IDS, Salmonella - SaDS, Shigella - ShDS); Mean bacterial count in laboratory wastewater 'LB' (E. coli - ELB, faecal coliforms - FLB, intestinal enterococci - ILB, Salmonella - SaLB, Shigella - ShLB); Mean bacterial count in laundry wastewater 'LD' (E. coli - ED, faecal coliforms - FLD, intestinal enterococci - ILD, Salmonella - SaLD, Shigella - ShLD).

Relationship between levels of bacteria in diarrheagenic stools and wastewaters

The mean counts of $E$. coli in diarrheagenic stools showed positive correlation with the count of $E$. coli $(r=0.657)$, intestinal enterococci $(r=0.654)$, Salmonella $(r=0.595)$, Shigella $(r=0.531)$ in the laboratory wastewaters. In addition, the mean faecal coliform counts in diarrheagenic stools showed positive correlation with the count of $E$. coli ( $r=0.664)$, intestinal enterococci $(r=0.648)$, Salmonella ( $r$ $=0.590)$, Shigella $(r=0.530)$ in the laboratory wastewaters.

Similarly, the mean bacterial counts of intestinal enterococci in diarrheagenic stools showed positive correlation with the count of E. coli $(r=0.542)$, intestinal enterococci ( $r=$ $0.680)$, Salmonella $(r=0.614)$, and Shigella $(r=$
0.512 ) in the laboratory wastewater. Also, the mean bacterial counts of Salmonella in diarrheagenic stools showed positive correlation with $E$. coli count $(r=0.650)$, intestinal enterococci $(r=0.677)$, Salmonella $(r=0.615)$, and Shigella $(r=0.541)$ in the laboratory wastewaters.

The mean bacterial count of Shigella in diarrheagenic stools showed positive correlation with the count of E. coli $(r=0.694)$, intestinal enterococci $(r=0.668)$, Salmonella $(r$ $=0.609)$, and Shigella $(r=0.549)$ in the laboratory wastewaters. There was no significant association between the levels of bacteria in diarrheagenic stools and the laundry wastewaters, with faecal coliforms $(r=0.312)$, Salmonella $(r=1)$ and Shigella $(r=1)$ as shown in Table 1. 


\section{Discussion:}

In this study, the correlation between faecal indicator bacteria (FIB) in diarrheagenic stools and hospital wastewaters with the implications and impacts of FIB on human health was evaluated. The high faecal coliform counts in diarrheagenic stools is in agreement with the observations of Sinton et al., (33) where the authors inferred that faecal coliforms are abundant in human faeces. The intestinal enterococci count in diarrheagenic stools also agrees with the reports of Boehm and Soller (11), and Boehm and Sassoubre (34), which noted that enterococci are found in high concentrations in human faeces but at a lower concentration when compared to the level of $E$. coli. Studies have reported $E$. coli as a predominant inhabitant of the gastrointestinal tract of humans $(4,5)$, and in human faeces, $90-100 \%$ of coliform bacteria isolated are $E$. coli (35). The large numbers of $E$. coli inhabiting the human gut and their absence in other environments backed their continual usage as the utmost subtle marker of faecal contamination (36).

Similarly, García-Aljaro et al., (37) reported that intestinal microbiome in healthy individuals serves as pointer to varying pathological conditions which cause diarrhea. This may account for the high $E$. coli count in diarrheagenic faecal samples in this study. The relatively high concentration of Salmonella species agrees with the findings of Jafari et al., (38) who observed high count of Salmonella spp from acute diarrhea patients at some hospitals in Tehran, and reported that Salmo nella spp constitutes significant human health hazard in that it presents diarrhea as one of its major clinical symptoms in humans. In the same vein, the high count of Shigella spp in diarrheagenic stools in this study agrees with the observations of Majalan et al., (39) who detected high Shigella count among diarrhea patients admitted to certain hospitals in Tehran. Moghanloo et al., (40) also detected Salmonella and Shigella species in stools of patients with diarrhea in Kashan City, Iran.

The high faecal coliform count observed in laboratory and laundry wastewater samples agrees with the findings of Chukwu et al., (41) who detected high total faecal coliform count (TFCC) of $2.9 \times 10^{3}$ and $2.4 \times 10^{2} \mathrm{CFU} / \mathrm{ml}$ respectively from laboratory and laundry wastewater samples collected from Abia State University Teaching hospital, Aba, Nigeria. Our observation is also in agreement with Sadek et al., (42) who detected significant levels of faecal coliforms in hospital discharges, thus indicating the level of faecal pollution of the receiving environment. Studies have demonstrated that the discharge of raw wastewater from hospices may have undesirable consequences and a considerable impact on public health as a result of constituents such as pathogenic organisms also including antibiotic resistant organisms, innocuous chemicals, chemotherapeutic remains, pharmaceutical materials, and irradiated isotopes $(43,44)$.

In our study, the low count of intestinal enterococci in laundry and laboratory wastewater samples agree with Moges et al., (45) who observed low levels of enterococci in wastewater samples from hospital environment in Northern Ethiopia. However, E. coli counts in laundry and laboratory wastewater samples were higher than those observed by Moges et al., (45). Other studies have established the presence of $E$. coli in habitats outside the gastrointestinal tract such as hospital wastewaters $(45,46)$.

The correlation between counts of enteric bacteria in diarrheagenic stools with those in wastewaters generated in the laboratory in this study may not be unconnected with the fact that faecal marker bacteria are usually commensals of the alimentary tract of many warm-blooded animals especially humans, and are passed out in faeces in large quantities. These enteric bacteria are also present in considerable quantity in faecallycontaminated waters in the hospital environment (47). The positive correlation between $E$. coli in diarrheagenic stools and E. coli, intestinal enterococci, Salmonella and Shigella spp in laboratory wastewater could be a consequence of high rate of uninterrupted discharge of faecal samples from the laboratory after necessary diagnostic procedures into wastewater. This bears some semblance with the findings of Patra et al., (48) who showed positive significant correlation of $E$. coli in stool samples with presumptive E. coli, Shigella, and Salmonella spp in laboratory wastewaters.

The positive correlation of faecal coliforms in diarrheagenic stools with $E$. coli, intestinal enterococci, Salmonella and Shigella spp in laboratory wastewater samples may indicate the discharge of un-disinfected faeces into hospital effluents (49). This also buttress the observations of Patra et al., (48) who showed positive significant correlation of faecal coliforms in diarrheagenic stools with presumptive E. coli, Shigella, Salmonella spp in laboratory wastewaters. The significant correlation observed between intestinal enterococci in diarrheagenic stool samples with intestinal enterococci, Salmonella and Shigella spp in 
laboratory wastewaters is comparable to the findings of Schriewer et al., (4) who observed significant correlation between intestinal enterococci from diarrheagenic faecal samples and Salmonella spp in laboratory wastewater samples. In contrast, a study conducted by Hatha et al., (50), observed no significant correlation between high levels of faecal coliforms in diarrheagenic stools and incidence of specific pathogens such as Salmonella and Shigella spp in laboratory wastewaters. The positive correlation observed between Salmo nella spp in diarrheagenic stools and $E$. coli, intestinal enterococci, Salmonella and Shigella spp in laboratory wastewaters agrees with the findings of Efstratiou et al., (51), where the authors observed a strong direct correlation between indicator bacteria (enterococci and $E$. coli) in wastewater samples and Salmonella spp in stool samples but contrastingly, the study by Polo et al., (52) reported little or no correlation of indicator bacteria in hospital wastewater samples with Salmonella spp from stool samples.

In the study by McEgan et al., (53), weak direct correlation between natural markers ( $E$. coli and coliforms) in hospital wastewaters and Salmonella levels in stool samples was reported, which may suggests that E. coli and coliforms are not absolute markers of the presence of pathogenic enteric bacteria such as Salmonella and Shigella spp in diarrheagenic stool samples, because there could also be contaminations by pathogens from non-faecal sources of the wastewaters in the hospital environment (54). The positive correlation reported between Shigella spp in diarrheagenic stools and levels of $E$. coli, intestinal enterococci, Salmonella and Shigella spp in hospital wastewater samples is comparable to the results of Ferguson et al., (55), who reported statistically significant correlations of bacterial pathogens such as Salmonella and Shigella spp in hospital wastewater with faecal indicators in stool samples.

\section{Conclusion:}

Our study demonstrates significant correlation between faecal indicator bacteria in diarrheagenic stools and laboratory wastewaters. The findings suggest that diarrheagenic stools should be disinfected after the performance of laboratory diagnostic tests in order to prevent onward transmission of potential pathogens in hospital settings. In addition, wastewater generated from hospitals must be fully treated prior to discharge into the environmental milieu in order to protect human health.

\section{Acknowledgements.}

The authors acknowledge the assistance of laboratory technologists of the Microbiology Department, Federal University of Technology, Akure, towards the conduct of this study.

\section{Ethical approval:}

Ethical approval (NHREC/18/08/2016 and a protocol number of OSHREC/16/09/ 2019/245) for the study were obtained from the Ondo State Health Research Ethics Committee (OSHREC) of the Ministry of Health $(\mathrm{MOH})$, Ondo State, Nigeria.

\section{Source of funding:}

No funding was received for the study.

\section{Conflict of interest:}

Authors declare no conflict of interest.

\section{References:}

1. Verlicchi, P., Galletti, A., Petrovic, M., et al. Hospital effluents as a source of emerging pollutants: an overview of micro-pollutants and sustainable treatment options. J Hydrol. 2010; 389: 416-428

2. Prayitno, K. Z., Yanuwiadi, B., and Laksmono, R. Study of hospital wastewater characteristic in Malang city. Int J Eng Sci. 2013; 2: 13-16

3. Radha, K. V., Kalaivani, K., and Lavanya, R. A case study of Biological waste management in hospitals. Glob J Hlth Sci. 2009; 1 (1): 82 - 88

4. Schriewer, A., Miller, W. A., Byrne, B. A., et al. Presence of Bacteroidales as a predictor of pathogens in surface waters of the central California coast. Appl Environ Microbiol. 2010; 76 (17): 5802-5811

5. Ahmed, W., Sidhu, J. P. S., Smith, K., et al. Distributions of fecal markers in wastewater from different climatic zones for human fecal pollution tracking in Australian surface waters. Appl Environ Microbiol. 2015; 82 (4): 1316-1323

6. Pachepsky, Y. A., and Shelton, D. R. Escherichia coli and Faecal Coliforms in freshwater and estuarine Sediments. Crit Rev Environ Sci Technol. 2012; 41: 1067-1110

7. Olalemi, A. O., and Dauda, V. O. Monitoring of selected groundwater sources for faecal contamination using bacterial and viral fecal pollution markers. Int J Publ HIth Res. 2018; 6 (3): 83-92

8. Francy, D. S., Donna, N., and Myers, T. Escherichia coli and faecal coliform bacteria as indicators of recreational water quality. Water Resources Investigations Report 93-4083. http://pubs.usgs.gov/wri/1993/4083/report.pdf.

9. United States Environmental Protection Agency, (USEPA). Method 1604: Total coliforms and Escherichia coli in water by membrane filtration using a simultaneous detection technique (MI medium). EPA-821-R-02-024, 2002

10. Wade, T. J., Sams, E., Brenner, K. P., et al. Rapidly measured indicators of recreational water 
quality and swimming-associated illness at marine beaches: a prospective cohort study. Environ HIth 2010; 9:66

11. Boehm, A. B., Soller, J. A. Risks Associated with Recreational Waters: Pathogens and Faecal Indicators. In: Meyers, R. A. (eds) Encyclopedia of Sustainability Science and Technology. New York City, Springer 2011

12. Cunningham, S. A., Sloan, L. M., Nyre, L. M., et al. Three-Hour Molecular Detection of Campylobacter, Salmonella, Yersinia, and Shigella Species in Faeces with Accuracy as High as That of Culture. J Clin Microbiol. 2010; 48 (8): 2929-2933

13. Sur, D., Ramamurthy, T., Deen, J., et al. Shigellosis: Challenges and Management Issues. Indian J Med Res. 2004; 120 (5): 45-54

14. Byappanahalli, M. N., Nevers, M. B., Korajkic, A., et al. Enterococci in the environment. Microbiol Mol Biol Rev. 2012; 76 (4): 685-706

15. Roddie, C., Paul, J. P., and Benjamin, R. Allogeneic hematopoietic stem cell transplantation and norovirus gastroenteritis: a previously unrecognized cause of morbidity. Clin Infect Dis. 2009; 49: $1061-1068$

16. Stein, A., Voigt, W., and Jordan, K. Chemotherapy-induced diarrhea: pathophysiology, frequency and guideline-based management. Ther Adv Med Oncol. 2010; 2: 51-63

17. Bauer, T. M., Lalvani, A., and Fehrenbach, J. Derivation and validation of guidelines for stool cultures for enteropathogenic bacteria other than Clostridium difficile in hospitalized adults. JAMA. 2001; 285: 313-319

18. Beaugerie, L., and Petit, J. C. Microbial-gut interactions in health and disease in antibioticassociated diarrhoea. Best Pract Res Clin Gastroenterol. 2004; 18: 337-352

19. Cohen, S. H., Gerding, D. N., and Johnson, S Clinical practice guidelines for Clostridium difficile infection in adults: 2010 update by the Society for Healthcare Epidemiology of America (SHEA) and the Infectious Diseases Society of America (IDSA). Infect Contr Hosp Epidemiol. 2010; 31:431-455 Young, V. B., and Schmidt, T. M. Antibioticassociated diarrhea accompanied by large-scale alterations in the composition of the faecal microbiota. J Clin Microbiol. 2004; 42: 1203-1206

21. Whelan, K., and Schneider, S. M. Mechanisms, prevention, and management of diarrhea in enteral nutrition. Current Opin Gastroenterol. 2011; 27: 152-159

22. Young, V. B. The intestinal microbiota in health and disease. Curr Opin Gastroenterol. 2012; 28: 63-69

23. Brown, K. D. Pharmaceutically-active compounds in residential and hospital effluent, municipal wastewater, and the Rio Grande in Albuquerque, New Mexico, The University of New Mexico, 2011

24. Pauwels, B., and Verstraete, W. The treatment of hospital wastewater: an appraisal. J Water HIth. 2006; 4 (4): 405-416

25. Mahvi, A., Rajabizadeh, A., Fatehizadeh, A., et al. Survey wastewater treatment condition and effluent quality of Kerman province hospitals. World Appl Sci J. 2009; 7 (12): 1521-1525

26. Rogowska, J., Cieszynska-Semenowicz, M. Rataczyk, W., et al. Micro-pollutants in treated wastewater Ambio. Am J Human Environ. 2020; 49: 487-503

27. Emmanuel, E., Perrodin, Y., Keck, G., et al. Ecotoxicological risk assessment of hospital wastewater: a proposed framework for raw effluents discharging into urban sewer network. J Hazard Mat. $2004 ; 117$ (1): 1-11

28. Jolibois, B., and Guerbet, M. Hospital wastewater geno-toxicity. Ann Occup Hyg. 2006; 50 (2): 189-
196

29. World Health Organization. Safe management of wastes from health-care activities. A summary, WHO, 2017.

30. Aluyi, A. S. A., Ekhaise, O. F., and Adelusi, M. D. Effect of human activities and oil pollution on the microbiological and physiological quality of Udu River, Warri, Nigeria. J Appl Sci. 2005; 6 (5): 1214-1219

31. Obire, O., Nwaubeta, O., and Adue, S. B. N. Microbial Community of a Waste-Dump Site. J Appl Sci Environ Managt. 2002; 6:78-83

32. Maheux, A. F., Picard, F. J., Boissinot, M., et al. Analytical limits of three glucosidase-based commercial culture methods used in environmental microbiology, to detect enterococci. Water Sci Technol. 2009; 60: 943-955

33. Sinton, L. W., Finlay, R. K., and Hannah, D. J. Distinguishing human from animal faecal contamination in water. NZ J Mar Freshwater Res. 1998; 32 (2): 323-348

34. Boehm, A. B., and Sassoubre, L. M. Enterococci as indicators of environmental faecal contamination. In: Gilmore, M. S., Clewell, D. R., Ike, Y., et al., (eds). Enterococci: From commensals to leading causes of drug resistant infection. Boston, Massachusetts Eye and Infirmary, 2014.

35. Hurst, C. J., Crawford, R. L., Knudsen, G. R., et al. Manual of Environmental Microbiology., 2nd ed. ASM Press, Washington DC, 2002

36. Teshome, B., Teklemariam, Z., Ayama, A. A., et al. Salmonella and Shigella among patients with diarrhea at Public Health facilities in Adama, Ethiopia: Prevalence, Antimicrobial Susceptibility Pattern and associated factors. SAGE Open Med. 2019; 7: 1-8

37. García-Aljaro, C., Blanch, A. R., Campos, C., et al. Pathogens, faecal indicators and human-specific microbial source-tracking markers in sewage. J Appl Microbiol. 2018; 126 (3): 701-717

38. Jafari, F., Shokrzadeh, L., Midian, M., et al. Acute diarrhea due to entero-pathogenic bacteria in patients at hospitals in Tehran. Japan. Infect. Dis. 2008; 61: 269-273.

39. Majalan, P. V., Hajizade, A., Nazarian, S., et al. Investigating the prevalence of Shigella species and their antibiotic resistance pattern in children with acute diarrhea referred to selected hospitals in Tehran, Iran J Appl Biotechnol Rep. 2018; 5 (2): 70-74

40. Moghanloo, E., Khorshidi, A., Badameh, P., et al. Prevalence of Shigella and Other Pathogenic Gramnegative Bacteria in the Patients with Diarrhoea in Kashan City, Iran during 2015-2017. J Human Environ HIth Prot. 2018; 24 (3): 106-110

41. Chukwu, V. A., Oti, V. B., Nnadozie, T. N., et al. Microbiological and antimicrobial analysis of hospital wastewater discharge into the soil environment. South-Asian J Res Microbiol. 2018; 1 (2): $1-11$

42. Sadek, S., Harkaki, B. F., Elkharim, K., et al. The bacterial load of Hospital Discharges in Sidi Kacem, Morocco. Adv Microbiol. 2013; 3511-3514

43. Baquero, F., Martínez, J. L., and Canto, N. R. Antibiotics and antibiotic resistance in water environments. Curr Opin Biotechnol. 2008; 19:260-265

44. Amouei, A., Asgharnia, $H$., Fallah, $H$., et al. Characteristics of Effluent Wastewater in Hospitals of Babol University of Medical Sciences, Babol, Iran. HIth Scope. 2015; 4 (2): e23222

45. Moges, F., Endris, M., Belyhun, Y., et al. Isolation and Characterization of Multiple drug resistant bacterial pathogens from wastewater in hospital and non-hospital environments, North-western Ethiopia. BMC Res Notes. 2014; 7:1-6 
46. Anderson, K. L., Whitlock, J. E., and Harwood, V. J., Persistence of Differential Survival of Faecal Indicator Bacteria in Subtropical Waters and Sediments. Appl Environ Microbiol. 2005; 71(6): 3041-3048

47. Bunnapradist, S., Neri, L., and Wong, W. Incidence and risk factors for diarrhea following kidney transplantation and association with graft loss and mortality. Am J Kidney Dis. 2007; 51: 478-486

48. Patra, A. K., Acharya, B. C., and Mohapatra, A. Occurrence and distribution of bacterial indicators and pathogens in coastal waters of Orissa. Indian J Mar Sci. 2009; 38 (4): 474-480

49. Maier, R. M., Pepper, J. L., and Gerba, C. P. Environmental Microbiology, Academic, San Diego, CA, 2002

50. Hatha, M., Chandran, A., and Varghese, S. Increased Prevalence of Indicator and Pathogenic Bacteria in the Kumarakom Lake: A function of Salt Water Regulator in Vembanadu Lake, A Ramsar Site, Along West Coast of India, Proceedings of Taal 2007: The 12th World Lake Conference, 2008., 250-256.
51. Efstratiou, M. A., Mavridou, A., Richardson, S. C., et al. Correlation of bacterial indicator organisms with Salmonella spp., Staphylococcus aureus and Candida albicans in sea water. Lett Appl Microbiol. 1998; 26(5): 342-346

52. Polo, F., Figueras, M., Inza, I., et al. Relationship between presence of Salmonella and indicators of faecal pollution in aquatic habitats. FEMS Microbiol Lett. 1998; 160: 253-256

53. McEgan, R., Mootian, G., Goodridge, L. D., et al. Predicting Salmonella Populations from Biological, Chemical, and Physical Indicators in Florida Surface Waters. Appl Environ Microbiol. 2013: 79 (13): 4094-4105

54. Sonu, C. Occurrence of Escherichia coli in raw and disinfected water supply; Correlation with enteropathogens. J Environ Sci Toxicol Food Technol. 2013; 9(7): 46-55

55. Ferguson, A. S., Layton, A. C., Mailloux, B. J., et al. Comparison of faecal indicators with pathogenic bacteria and rotavirus in groundwater. Sci Total Environ. 2012; 1(431): 314-322 